\title{
DNA FINGERPRINTING OF HUMAN CELL LINES USING PCR AMPLIFICATION OF FRAGMENT LENGTH POLYMORPHISMS
}

\author{
RUI YAN, MARK OTTENBREIT, BHARATI HUKKU, MICHAEL MALLY, SHARONG CHOU, AND JOSEPH KAPLAN ${ }^{1}$
}

Cell Culture Laboratory, Children's Hospital of Michigan, 3901 Beaubien Boulevard, Detroit, Michigan 48201 (all authors), and Department of Pediatrics, Wayne State University School of Medicine, 3901 Beaubien Boulevard, Detroit, Michigan 48201 (B. H., J. K.)

(Received 23 October 1995; accepted 24 January 1996)

\section{SUMMARY}

Methods for monitoring cell line identification and authentication include species-specific immunofluorescence, isoenzyme phenotyping, chromosome analysis, and DNA fingerprinting. Most previous studies of DNA fingerprinting of cell lines have used restriction fragment length polymorphism analysis. In this study, we examined the utility of an alternative and simpler method of cell line DNA fingerprinting-polymerase chain reaction (PCR) amplification of fragment length polymorphisms. Fourteen human cell lines previously found by other methods to be either related or disparate were subjected to DNA fingerprinting by PCR amplification of selected fragment length polymorphism loci. Cell identification patterns by this method were concordant with those obtained by isoenzyme phenotyping and restriction fragment length polymorphismDNA fingerprinting, and were reproducible within and between assays on different DNA extracts of the same cell line. High precision was achieved with electrophoretic separation of amplified DNA products on high resolution agarose or polyacrylamide gels, and with fragment length polymorphism (FLP) loci-specific "allelic ladders" to identify individual FLP alleles. Determination of the composite fingerprint of a cell line at six appropriately chosen fragment length polymorphism loci should achieve a minimum discrimination power of 0.999 . The ability of PCR-based fragment length polymorphism DNA fingerprinting to precisely and accurately identify the alleles of different human cell lines at multiple polymorphic fragment length polymorphism loci demonstrates the feasibility of developing a cell line DNA fingerprint reference database as a powerful additional tool for future cell line identification and authentication.

Key words: DNA fingerprinting; cell lines; polymerase chain reaction.

\section{INTRODUCTION}

The requirement for cell line authentication has a history almost as long as cell culturing itself, presumably beginning when more than one cell line could be cultured continuously. The need today is as great as it was 35 years ago when cell banks were first established to provide characterized cell lines. Of the 2376 cell lines submitted to us for characterization in the past 7 years, $166(7 \%)$ were found to be cross-contaminated by cells of the same or different species. Roughly two-thirds of the contaminated human cell lines were crosscontaminated by other human cell lines. Because most facilities culturing cells use multiple cell lines, and because the complexity of experimental design and the broad use of cell lines in scientific investigation and in the pharmaceutical and biotechnology industries continues to increase, the possibility of inadvertent admixture of cell lines during the course of day-to-day cell culture is always present. Cell line authentication and early detection of contamination of one cell line with another can prevent mistaken interpretation of the results of experiments involving their use, and is essential for maintaining the safety and efficacy of vaccines, monoclonal antibodies, and other pharmacological agents derived from cell lines.

The great increase in interest and use of cell culture systems that began with the virologists in the early 1950 s and then spread to all

\footnotetext{
'To whom correspondence should be addressed.
}

fields of biology led to a reexamination of the status of the many cell lines extant in the early 1960s. Use of cell species markers including chromosomes $(21)$ and species surface antigens $(1,5,23)$ showed that interspecies contamination was fairly widespread. In 1967, Gartler introduced isoenzymic analysis for identifying human cell lines. $\mathrm{He}$ showed that intraspecies contamination of human cell cultures had also become a serious problem and that many of the human tumor cell lines in use at that time were actually derived from a single source, i.e., the HeLa cell line $(2,3)$. Subsequently, this approach was extended to incorporate the use of multiple polymorphic isoenzymes for more precise cell line identification $(17,25)$. The demonstration in 1971 by Miller et al. (12) that HeLa cells had marker chromosomes that were persistent and readily identifiable firmly established the power of chromosome analysis as a means of cell identification and detection of intraspecies contamination. Using detection of these marker chromosomes, Nelson-Reese then convincingly demonstrated that multiple tumor cell lines under active investigation represented HeLa contaminants $(14,15,16)$.

Although unique marker chromosomes in general have proven extremely useful in the authentication of cell cultures, new marker chromosomes may evolve during long-term culture from ongoing chromosome rearrangements which can confound attempts to resolve relationships and distinctions between different cell lines. DNA fingerprinting has been used to help resolve this type of problem $(4,24)$. 
The methodology is based on the existence in the genome of dispersed hypervariable regions of tandem-repetitive nucleotide sequences (9). Polymorphism within a given species is due to the existence within that species of multiple different alleles, each of which encodes a different number of tandem repeats of the core nucleotide sequence characteristic of that region. The most polymorphic tandem repeats are those with long core sequences (e.g., 15 base pairs) called "variable number of tandem repeats" (VNTR) or "minisatellites" $(9,13)$. Those with core sequences of a few base pairs (e.g., 1 to 5 bp) are called "short tandem repeats" (STR) or "microsatellites" (25).

Several different approaches to DNA fingerprinting of cell lines have been described. One approach involves restriction fragment length polymorphism (RFLP) analysis by the Southern blot technique with multilocus VNTR probes which bind to several different hypervariable regions distributed on many different chromosomes. This procedure results in blots with a complex pattern of bands permitting ready distinction between different cell lines $(4,24)$. However, when mixtures of different cell lines occur, the band patterns are not easily analyzed (19). Moreover, the difficulty in resolving the size of each of the many bands makes this approach somewhat tedious, and the results are not readily tabulated. Hence, the creation of a crossreference database is cumbersome. An alternative approach which overcomes these limitations is the use of RFLP analysis with single locus polymorphism (SLP) probes which detect highly polymorphic VNTR unique to single gene loci. The VNTR of each single gene locus exhibit Mendelian inheritance, a high degree of heterozygosity, and a low mutation rate. When digested with restriction enzymes and analyzed by the Southern blot technique with SLP probes, these VNTR loci have the potential for generating a large number of unique size fragments characteristic of the many different alleles encoding that locus (13). Given the high degree of heterozygosity at each of these loci, each cell line usually yields two bands which can be accurately and reproducibly sized by comparison with molecular size standards. Application of four or five different SLP probes to a single enzyme digest yields a virtually unique cell line fingerprint. Unfortunately, although accurate and precise, this approach is complicated, labor-intensive, and time-consuming. Moreover, interassay standardization for purposes of developing a reference cell line DNA fingerprint database is problematic.

In this report, we describe a simpler and more rapid method of DNA fingerprinting human cell lines using PCR amplification of single locus polymorphisms of multiple VNTR or short tandem repeat (STR) origins, a procedure commonly referred to as AmpFLP (amplified fragment length polymorphism) analysis. We demonstrate the accuracy and precision of this DNA fingerprinting method, provide examples of how it can distinguish cell line contamination from genomic changes in a single cell line, and indicate its potential for generating a cell line DNA fingerprint reference database for DNAfingerprinted cell lines.

\section{Materials ano Methons}

Cell lines. Fourteen different freeze-stored adherent human cell lines selected from cultures previously sent to us for characterization or authentication by other investigators (Table 1) were thawed and cultured in MEM-E (modified Eagle's medium-Earle's salts, JRH Biosciences, Lenexa, KS) supplemented with $10 \%$ fetal bovine serum, $2 \%$ lactalbumin hydrolysate, $1 \%$ sodium pyruvate and $5 \mu \mathrm{g} / \mathrm{ml}$ gentamicin sulfate/ml. Before being frozen in liquid nitrogen at $-170^{\circ} \mathrm{C}$, each of the cell lines had been characterized by species-specific immunofluorescence, isoenzyme phenotyping, and chromosome analysis as previously described (7).
TABLE 1

CELL LINES ANALYZED

\begin{tabular}{|c|c|c|c|}
\hline Number & Name & Source & Description \\
\hline 25 & SW620 & $\begin{array}{l}\text { D. Scudiero } \\
\text { National Institutes of Health } \\
\text { Bethesda, MD }\end{array}$ & Colon carcinoma \\
\hline 76 & $\mathrm{~T} 24$ & $\begin{array}{l}\text { S. Aronson } \\
\text { National Institutes of Health, } \\
\text { Bethesda, MD }\end{array}$ & $\begin{array}{l}\text { Bladder } \\
\text { carcinoma }\end{array}$ \\
\hline 78 & 267B1\#AP3 & $\begin{array}{l}\text { M. Kuettel } \\
\text { Georgetown University, } \\
\text { Washington, DC }\end{array}$ & $\begin{array}{l}\text { Human tumor, } \\
\text { unknown source }\end{array}$ \\
\hline 86 & BRK401 & $\begin{array}{l}\text { Y. Tromvoukis } \\
\text { Nestle Research Centre, } \\
\text { Switzerland }\end{array}$ & Skin \\
\hline 89 & CENDO\#238 & $\begin{array}{l}\text { Y. Tromvoukis } \\
\text { Nestle Research Centre, } \\
\text { Switzerland }\end{array}$ & Conjunctiva \\
\hline 93 & HeLa & $\begin{array}{l}\text { R. Hay } \\
\text { ATCC, Rockville, MD }\end{array}$ & $\begin{array}{l}\text { Cervical } \\
\text { carcinoma }\end{array}$ \\
\hline 94 & AV3 & $\begin{array}{l}\text { R. Bell } \\
\text { (Difco Laboratories, } \\
\text { Detroit, MI) }\end{array}$ & Amnion \\
\hline 95 & HEP-2 & $\begin{array}{l}\text { E. Ades } \\
\text { CDC, Atlanta }\end{array}$ & Larynx carcinoma \\
\hline 96 & HeLaS3 & $\begin{array}{l}\text { J. Ziegenmeyer } \\
\text { Corning Medical \& Scientific, } \\
\text { East Walpole, MA }\end{array}$ & $\begin{array}{l}\text { Cervical } \\
\text { carcinoma }\end{array}$ \\
\hline 97 & $\begin{array}{l}\text { Chang } \\
\text { Conjunctiva }\end{array}$ & $\begin{array}{l}\text { E. Snow } \\
\text { CDC, Atlanta, GA }\end{array}$ & Conjunctiva \\
\hline 117 & MrHeLaS3 & $\begin{array}{l}\text { R. Goth-Goldstein } \\
\text { Lawrence-Livermore, } \\
\text { Berkeley, CA }\end{array}$ & $\begin{array}{l}\text { Cervical } \\
\text { carcinoma }\end{array}$ \\
\hline 118 & HeLaA6 & $\begin{array}{l}\text { L. Samson } \\
\text { Harvard University, } \\
\text { Boston, MA }\end{array}$ & $\begin{array}{l}\text { Cervical } \\
\text { carcinoma }\end{array}$ \\
\hline 119 & JRHeLa (7-89) & $\begin{array}{l}\text { R. Goth-Goldstein } \\
\text { Lawrence-Livermore, } \\
\text { Berkeley, CA }\end{array}$ & $\begin{array}{l}\text { Cervical } \\
\text { carcinoma }\end{array}$ \\
\hline 120 & JRHeLa (5-84) & $\begin{array}{l}\text { R. Goth-Goldstein } \\
\text { Lawrence-Livermore, } \\
\text { Berkeley, CA }\end{array}$ & $\begin{array}{l}\text { Cervical } \\
\text { carcinoma }\end{array}$ \\
\hline 121 & RHeLa & $\begin{array}{l}\text { R. Goth-Goldstein } \\
\text { Lawrence-Livermore, } \\
\text { Berkeley, CA }\end{array}$ & $\begin{array}{l}\text { Cervical } \\
\text { carcinoma }\end{array}$ \\
\hline
\end{tabular}

Genomic DNA isolation. One to two million cultured cells were harvested, trypsinized, and spun down to $100 \mu \mathrm{l}$ in a microcentrifuge tube. Genomic DNA was isolated with a Genomix Micromix Isolation Kit (Washington Biotechnology, Inc., Bethesda, MD) and was then was dissolved in $50 \mu \mathrm{l}$ distilled water and stored at $-20^{\circ} \mathrm{C}$.

FLP loci. Ten FLP loci were examined in this study (Table 2). The population frequency of the most common alleles was $0.28-0.44$ and the estimated percentage heterozygosity in the general population was $54-79 \%$.

Oligonucleotide primers. PCR primers for the VNTR loci of MCT118 (11) and YNZ22 (26) were synthesized on a DNA and RNA Synthesizer, Model 394 (Applied Biosystems, Foster City, CA) by the Macromolecular Core Facility of Wayne State University. The primers were used without further purification. The primer sequences are: MCT118 5', GAAACTGGCCTCCAAA CACTGCCCGCCG, MCT1183', GTCTTGTTGGAGATGCACGTGCCCCTTG 
TABLE 2

FRAGMENT LENGTH POLYMORPHISM (FLP) LOCI TESTED

\begin{tabular}{|c|c|c|c|}
\hline FLP Locus & $\begin{array}{l}\text { Chmmosome } \\
\text { Lacation }\end{array}$ & $\begin{array}{l}\text { Most Frequent } \\
\text { Allele }(P)\end{array}$ & $\begin{array}{c}\text { Percent } \\
\text { Heterozygosity }\end{array}$ \\
\hline MCT118 & lp & $0.41^{a}$ & 79 \\
\hline CSF1P0 & $5 \mathrm{q} 33.5-34$ & $0.33^{b}$ & 74 \\
\hline FESFPS & 15q25-qter & $0.39^{5}$ & 70 \\
\hline YNZ22 & 17 & $0.4^{c}$ & 78 \\
\hline vWF & 12p12-pter & $0.28^{d}$ & 73 \\
\hline THO1 & $11 \mathrm{p} 15.5$ & $0.29^{\circ} f$ & 77 \\
\hline F13AO1 & $6 p 24-24$ & $0.35^{b}$ & 73 \\
\hline TPOX & $2 p 13$ & 0.448 & 67 \\
\hline HPRTB & $X q 26$ & 0.34 & 78 \\
\hline F13B & 1q31-q32.1 & $0.39^{h}$ & 66 \\
\hline LPL & $8 p 22$ & $0.44^{b}$ & 54 \\
\hline
\end{tabular}

${ }^{\circ}$ Rand et al. Int. J. Leg. Med. 104:329-333; 1992.

${ }^{6}$ Hammond et al. Am. J. Hum. Genet. 55:175-189; 1994.

-Ugozolli et al. Blood 77:1607-1615; 1991.

${ }^{d}$ Kimpton et al. Hum. Mol. Genet. 1:287; 1992.

- Puers et al. Am. J. Hum. Genet. 53:953-958; 1993.

'Edwards et al. Genomics 12:241-253; 1992.

s Anker et al. Hum. Mol. Genet. 1:137; 1992.

${ }^{h}$ Nishimura et al. Nucleic Acids Res. 20:1167; 1992.

\section{C; YNZ22 5', CGAAGAGTGAAGTGCACAGG, YNZ22 3', CACAGTCTTT} ATTCTTCAGCG.

PCR primers for STR were those provided in the GenePrint STR Systems Kit (Promega, Madison, WI).

Polymerase chain reaction amplification of fragment length polymorphisms $(A m p F L P)$. Polymerase chain reaction amplifications of VNTR loci were carried out in $5 \%$ DMSO, $50 \mathrm{~m} M \mathrm{KCl}, 10 \mathrm{mM}$ Tris-HCl pH 9.0, 0.1\% Triton $\mathrm{X} 100,1.5 \mathrm{~m} M \mathrm{MgCl}_{2}, 200 \mu M$ of each deoxynucleoside triphosphate, $0.4 \mu M$ of each primer, 2.5 units of Taq (DNA polymerase) (Perkin-Elmer Cetus, Norwalk, CT), and $20 \mathrm{ng}$ of genomic DNA in a 40- $\mu$ l final volume. The PCR amplifications of the STR loci were performed with a commercially available kit (Perkin-Elmer Cetus, Norwalk, CT) according to the manufacturer's technical manual. Precautionary measures taken to prevent cross-contamination of PCR reactions included use of separate working areas for DNA isolation and PCR amplification, and use of separate pipette tips and gloves for each individual cell line DNA isolation. To confirm the absence of cross-contamination, control PCR amplifications were routinely carried out in the absence of template DNA, and in all instances these were negative.

The PCR reactions were performed on a RoboCycler 40 (Stratagene, La Jolla, CA). Different thermal cycle programs were used for different loci as follows: locus DlS80-denaturation at $94^{\circ} \mathrm{C}$ for $1 \mathrm{~min}$, annealing at $66^{\circ} \mathrm{C}$ for $1 \mathrm{~min}$, and extension at $72^{\circ} \mathrm{C}$ for $2 \mathrm{~min}$ for a total of 30 cycles; locus YNZ22-denaturation at $94^{\circ} \mathrm{C}$ for $1 \mathrm{~min}$, annealing at $61^{\circ} \mathrm{C}$ for $1 \mathrm{~min}$, and extension at $72^{\circ} \mathrm{C}$ for $2.5 \mathrm{~min}$ for a total of 35 cycles; STR loci--denaturation at $94^{\circ} \mathrm{C}$ for $1 \mathrm{~min}$, annealing at $60^{\circ} \mathrm{C}$ or $64^{\circ} \mathrm{C}$ for $1 \mathrm{~min}$ depending on the locus, and extension at $72^{\circ} \mathrm{C}$ for $2 \mathrm{~min}$ for a total of 30 cycles. All of the thermal cycle programs were linked to a hot start program at $95^{\circ} \mathrm{C}$ for 5 min and then at $72^{\circ} \mathrm{C}$ for $5 \mathrm{~min}$, and were tagged by a soaking program at $72^{\circ} \mathrm{C}$ for $7 \mathrm{~min}$ after amplification.

Size analysis of PCR products. The size of each PCR-amplified VNTR was analyzed by gel electrophoresis on $1 \%$ agarose gels. The MCT118 and YNZ22 loci PCR-amplifed products were analyzed on 0.5-mm $1 \times$ GDG gels (GeneAmp Detection Gel, Perkin-Elmer Cetus, Norwalk, CA) in $0.5 \times$ Trisborate (TBE) buffer nun at $500 \mathrm{~V}$ for 2 to $3 \mathrm{~h}$. The MCT118 locus PCRamplified products were typed with the AmpliFLP DIS80 (i.e., MCT118) allelic ladder (Perkin-Elmer Cetus, Norwalk, CA). A 100-bp DNA ladder (GIBCO BRL, Grand Island, NY) was used to determine the size of the amplified DNA bands at locus YNZ22, because the reported range of PCR products at locus YNZ22 is from about $0.2 \mathrm{~kb}$ to $1.5 \mathrm{~kb}$ with the core sequence of 70 base pairs (26). The size of the PCR-amplified products of the STR loci were analyzed on a $0.4-\mathrm{mm} 4 \%$ denaturing polyacrylamide gel in $7 M$ urea and $1 \times$ TBE. The DNA samples were mixed with an equal volume of $2 \times \mathrm{STR}$ denaturing buffer, heated at $95^{\circ} \mathrm{C}$ for $3 \mathrm{~min}$, and chilled on ice.
The gel was run in $1 \times$ TBE at $50 \mathrm{~W}$ for 1 to $2 \mathrm{~h}$ according to the size of the locus examined. Commercial allelic ladders were used to indicate the alleles of the DNA samples at all STR loci.

The DNA bands were visualized by silver staining. The gel was fixed in $10 \%$ acetic acid for $30 \mathrm{~min}$ with agitation, stained in $0.1 \%$ silver nitrate plus 6\% formaldehyde for $30 \mathrm{~min}$ with agitation, and developed in a solution of $3 \%$ sodium carbonate, $6 \%$ formaldehyde, and $8 \mathrm{mM}$ sodium thiosulfate. The banding patterns were retained as permanent records by duplication on EDF films (Electrophoresis Duplicating Film, Kodak, Rochester, NY).

Isoenzyme assay. Isoenzymes glucose-6-phosphate dehydrogenase (G6PD) phosphoglucomutase-1 (PGM1), phosphoglucomutase-3 (PGM3), esterase D (ESTD), malic enzyme, mitochondrial (Me-2) and glyoxalase-1 (GLOl) were analyzed by an agarose electrophoresis method as previously reported (18).

\section{RESULTS}

Comparison of cell lines by AmpFLP analysis and isoenzyme phenotyping. Nine human cell lines were characterized in parallel by AmpFLP at four hypervariable tandem repeat loci (MCT118, CSF1PO, FESFPS, and THO1), and by isoenzyme phenotype analysis of six different human isoenzymes (G6PD, PGM1, PGM3, ESTD, $\mathrm{Me}-2$, and GLO1). These nine cell lines were chosen on the basis of the results of previous isoenzyme phenotyping and chromosome analyses performed in this laboratory. Type B G6PD cell lines 25,76 , 78 , and 89 had been shown to be individual cell lines by isoenzyme and cytogenetic examination, whereas cell line 93 (HeLa) and the four type A G6PD cell lines 94, 95, 96, and 97 all showed the characteristics previously shown for HeLa cells, including the characteristic distribution of marker chromosomes.

The AmpFLP analysis revealed that the DNA fingerprints of cell lines $25,76,78$, and 89 (lanes $b, c, d$, and $e$ ) were clearly distinct from each other (Fig. 1). They also differed from the uniform DNA fungerprint obtained with cell lines 93, 94, 95, 96, and 97 (lanes $f$ $j$ ). For each cell line, the allelic repeat numbers for each fragment at each locus can be readily assigned by comparison with the predetermined "allelic ladders" in lanes $a$ and $k$.

Table 3 lists for all nine cell lines the AmpFLP-defined allele makeup at each of the four tandem repeat loci, and the cell line phenotype for each of six isoenzymes. The results of the two identification methods were concordant. Cell lines 25, 76, 78, and 89 all had distinct AmpFLP-defined DNA fingerprints and isoenzyme profiles, whereas cell lines $93,94,95,96$, and 97 all shared identical DNA fingerprints and isoenzyme phenotypes. The AmpFLP fingerprint profiles lend themselves to database entry in much the same way that the isoenzyme profiles do. For example, cell line 25 may be characterized by the notation $18 / 21,13 / 14,13$, and 8 for loci MCT118, CSF1PO, FESFPS, and THO1 respectively, a genotype which distinguishes it from any of the other nine cell lines in this series.

Intraassay and interassay precision of AmpFLP-DNA fingerprinting of cell lines. To demonstrate the precision and stability of AmpFLP fingerprinting of cell lines, cells from cell line 93 (HeLa) were divided into three aliquots for DNA extraction. Each DNA aliquot was then amplified in three parallel PCR reactions. All of the PCR products were analyzed on $1 \times$ GDG gel, and each gel electrophoresis was repeated once. The DNA fingerprinting profile of locus MCT118 did not vary between different DNA extractions, PCR amplifications, or gel electrophoresis runs (Fig. 2, top and bottom). Fingerprinting profiles were also consistent between cell line 93 (HeLa) and its derivative cell lines 94, 95, 96, and 97 (lanes $l$ to $o$ ).

Analysis of variant HeLa sublines. Whereas chromosomal and isoenzyme phenotype stability are characteristics that enable one to 


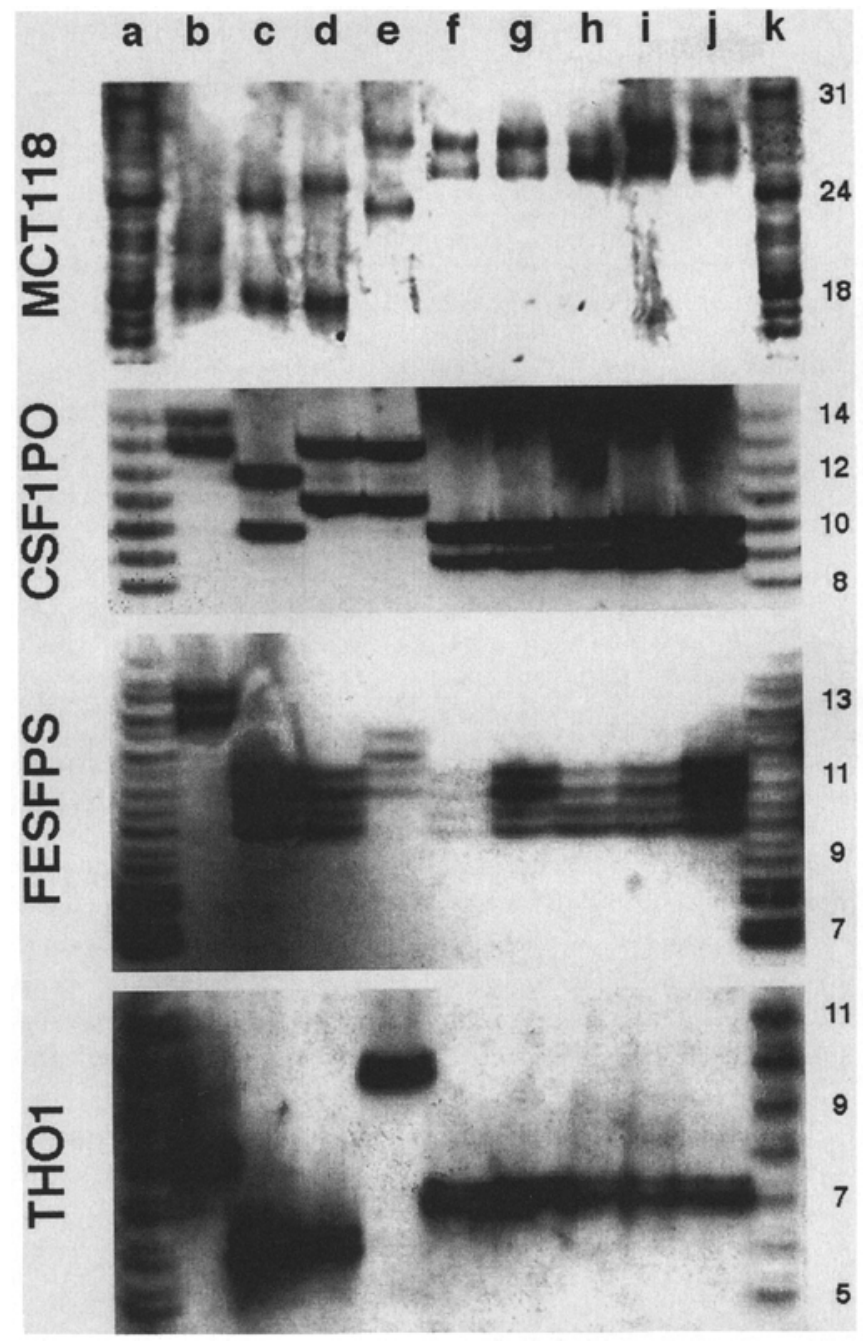

FIG. 1. DNA fingerprinting at FLP loci MCT118, CSF1PO, FESFPS, and THO1. Lanes $a$ and $k$, allelic ladders of each corresponding locus. Lanes $b$ through $j$, cell lines $25,76,78,89,93,94,95,96$, and 97 . The alleles of each cell line at each locus as defined by the numbers of tandem repeats detected at each locus are listed in Table 2.

identify cell lines with certainty, occasionally, after viral infection, irradiation, chemical treatment, or even multiple passage in vitro, alterations in normal or marker chromosome array occur which may alter the isoenzyme phenotype due to a loss of heterozygosity $(6,27)$. Such changes can make it difficult to identify a particular cell line with certainty. We examined an example of such change with the aid of AmpFLP fingerprinting.

Five putative HeLa cell lines were submitted for characterization. The isoenzyme phenolype and cytogenetic profiles (including marker chromosomes) of two of these, cell lines 119 and 121, were consistent with HeLa cell derivatives. By contrast, the profiles obtained with the other three cell lines-117, 118, and 120-were inconsistent with HeLa. Although five isoenzyme phenotypes were in accordance with HeLa, the G6PD was aberrant, that is, its mobility was slower than that of the A+ isotype characteristic of HeLa, so much so that it could be (and was) interpreted to be a B + mobility. In addition, and perhaps more importantly, none of the marker chromosomes associated with the HeLa cell line could be identified. All three of these cell lines showed two $X$ chromosomes with $q$ arm deletions which might account for the abnormal mobility of G6PD. The RFLP fingerprinting analysis kindly carried out by Y. Reid (ATCC, Rockville, MD) on one of the three aberrant cell lines indicated a possible relationship to HeLa (personal communication).

We analyzed all five putative HeLa cell lines together with the standard HeLa cell line by applying PCR-based AmpFLP fingerprinting at two VNTR and nine STR loci. The alleles detected by the AmpFLP analysis at each locus are shown in Table 4, and the gel mobility patterns at each locus for each of the five test "HeLa" cell lines are shown in Figure 3. The standard HeLa cell line (cell line 93) and all five of the test cell lines are identical for alleles at seven FLP loci (vWF, THO1, F13A01, TPOX, HPRTB, F13B, and LPL). As discussed later, this indicates with certainty that the five test cell lines are all HeLa cell derivatives. At each of the other four FLP loci (MCT118, CSF1PO, FESFPS, and YNZ22) cell lines 119 and 121 , like the standard HeLa cell line, exhibit heterozygosity for the same two alleles. By contrast, cell lines 117,118 , and 120 exhibit only one of these same two alleles. These results show that compared to the parental HeLa cell line, cell lines 117, 118, and 120 have lost heterozygosity at loci MCT118, CSF1P0, and FESFPS on chromosomes 1, 5, and 15, respectively. Additionally, cell line 117 appears to have lost heterozygosity at locus YNZ22 on chromosome 17, and cell line 121 appears to have gained an extra allele at locus vWF.

\section{Drscussion}

AmpFLP-DNA fingerprinting appears to provide accurate and precise information concerning the relatedness and distinction between cell lines. The identification patterns obtained are concordant with those obtained by isoenzyme phenotyping and RFLP-DNA fingerprinting, and are reproducible within and between assays on different DNA extracts of the same cell line. This demonstration of the application of AmpFLP-DNA fingerprinting to the identification and characterization of human cell lines is concordant with findings presented in a previously published preliminary report by Reid et al. $(19,20)$.

Two technical factors have been found to be particularly important in achieving precision with the AmpFLP cell line fingerprinting method. One is the use of polyacrylamide gels during electrophoretic separation of amplified STR DNA products which readily permits distinction between bands differing by only three nucleotide base pairs. The other is the use of FLP-specific "allelic ladders" which permits more consistent and accurate identification of individual alleles than the use of standard lambda phage DNA restriction fragment "sizing ladders." By comparing unknown alleles and allelic ladder fragments in each individual gel, it is possible to compare alleles on different gels because both test and standard "allelic ladder" fragments migrate identically in different gels. By contrast, the relative migrations of alleles and "sizing ladder" fragments may differ in different gels.

Comparison of the frequency of heterozygosity at each of the FLP loci studied here in the general population (Table 2) and in the tested cell lines (Tables 3 and 4) indicates that the tested cell lines have a higher than expected frequency of a single allele at some FLP loci. For example, all 4 non-HeLa cell lines and all $10 \mathrm{HeLa-derived} \mathrm{cell}$ lines have one rather than two different alleles at the THOl locus. One possible explanation for such a finding is "pseudohomozygos- 
TABLE 3

AmpFLP DNA FINGERPRINTS AND ISOENZYME PHENOTYPES

\begin{tabular}{|c|c|c|c|c|c|c|c|c|c|}
\hline \multirow{2}{*}{ 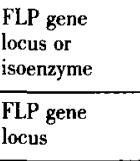 } & \multicolumn{9}{|c|}{$\begin{array}{c}\text { Cell Lines } \\
\text { (Repeat size of FLP alleles detected) }\end{array}$} \\
\hline & 25 & 76 & 78 & 89 & 93 & 94 & 95 & 96 & 97 \\
\hline MCT118 & $18 / 21$ & $18 / 24$ & $18 / 25$ & $24 / 28$ & $26 / 28$ & $26 / 28$ & $26 / 28$ & $26 / 28$ & $26 / 28$ \\
\hline CSF1PO & $13 / 14$ & $10 / 12$ & $11 / 13$ & $11 / 13$ & $9 / 10$ & $9 / 10$ & $9 / 10$ & $9 / 10$ & $9 / 10$ \\
\hline FESFPS & 13 & $10 / 11$ & $10 / 11$ & $11 / 12$ & $10 / 11$ & $10 / 11$ & $10 / 11$ & $10 / 11$ & $10 / 11$ \\
\hline THOl & 8 & 6 & 6 & 10 & 7 & 7 & 7 & 7 & 7 \\
\hline Isoenzyme & \multicolumn{9}{|c|}{ Isoenzyme Phenotype } \\
\hline G6PD & B & B & B & B & A & A & $\mathrm{A}$ & $A$ & A \\
\hline PGM1 & 2 & 1 & 1 & 2 & 1 & 1 & 1 & 1 & 1 \\
\hline PGM3 & 1 & 1 & $1-2$ & $1-2$ & 1 & 1 & 1 & 1 & 1 \\
\hline ESTD & 1 & 1 & 1 & $1-2$ & 1 & 1 & 1 & 1 & 1 \\
\hline $\mathrm{Me}-2$ & 1 & 2 & 一 & - & $1-2$ & $1-2$ & $1-2$ & $1-2$ & $1-2$ \\
\hline GLO-1 & 2 & 1 & $1-2$ & 1 & 2 & 2 & 2 & 2 & 2 \\
\hline
\end{tabular}

${ }^{a}$ Cell lines 25-93 are all different lines. Cell lines 93-97 are all HeLa derivatives.

ity," an AmpFLP-specific phenomenon which can result from either failure of PCR amplification of the larger of two tandem repeat alleles (22) or failure to amplify a specific tandem repeat unit because of the presence of "null" or O-type repeats that block priming with one of the two primers (9). However, neither of these technical artifacts is likely to account for the current results. The former is characterized by complete failure to detect heterozygosity at a specific locus, and we have observed heterozygosity at the THO1 locus in other cell lines using the same AmpFLP fingerprinting methodology. The latter is characterized by specific local gaps in the allelic ladder at certain homozygous positions and by band intensity differences, but we de- tect no such allelic ladder gaps or band intensity differences in AmpFLP fingerprints of the THO1 locus (Figure 2). Because many long-term-passaged cell lines are aneuploid and have both gained and lost normal chromosomes and chromosomal material, it seems far more likely that cell lines have a relatively high frequency of single alleles at FLP loci because they have a relatively high frequency of true hemizygosity $(6,8)$.

The development of hemizygosity within sublines of a parent cell line is well illustrated by comparison of the DNA fingerprints of the "conventional" and "atypical" HeLa cell lines analyzed here. Thus, it is clearly evident from their identity with the standard HeLa cell

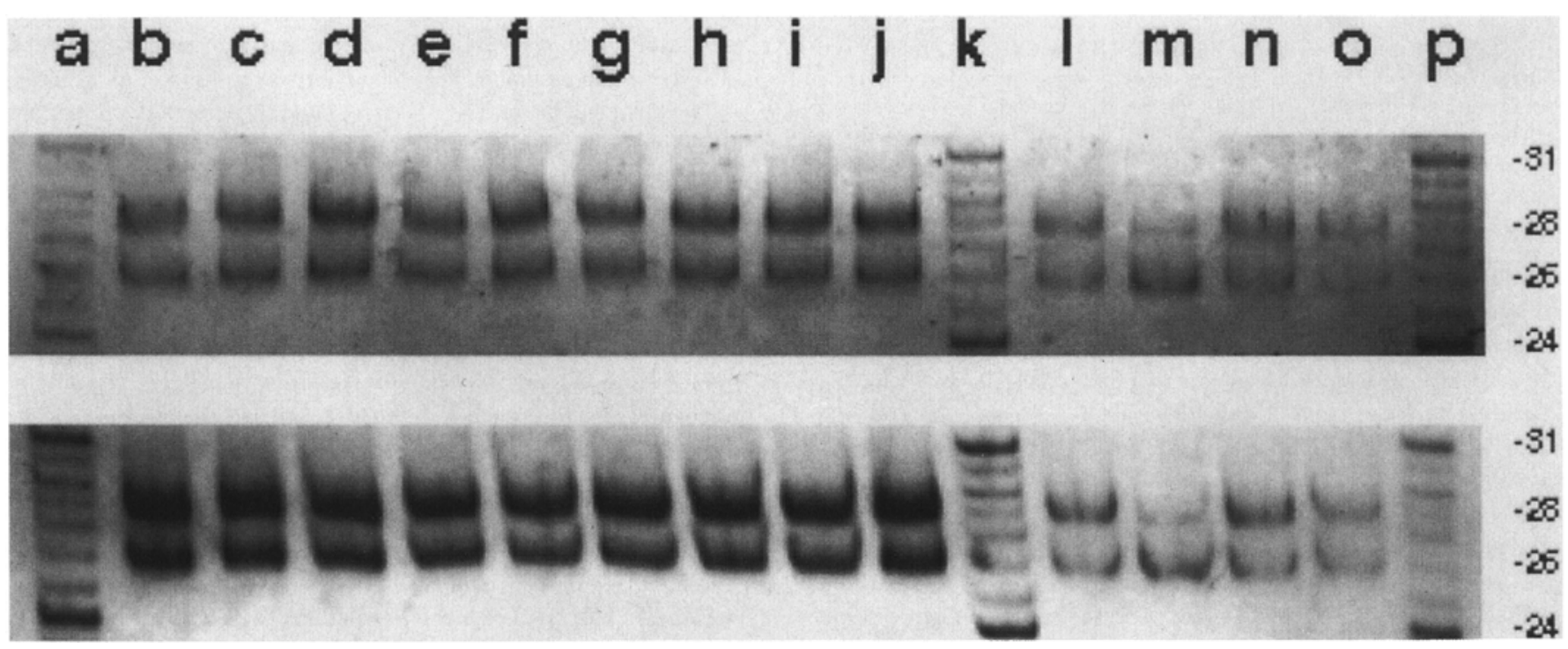

FIG. 2. Consistency of DNA fingerprinting. Lanes $a, k$, and $p$, AmpFLP DIS80 allelic ladder. Lanes $b$ through $j$, amplified fragments from three aliquots of DNA extraction of cell line 93; each DNA sample was tested in three parallel PCR amplifications. Lanes $l$ through $o$, cell lines 94-97. The upper and the lower panels show the results of two parallel gel electrophoreses. The amplified DNA fragments match the allelic ladder at alleles $26,28$. 
TABLE 4

AmpFLP-DNA FINGERPRINTING OF HeLa SUBLINES

\begin{tabular}{|c|c|c|c|c|c|c|}
\hline \multirow[b]{2}{*}{ FLP locus } & \multicolumn{6}{|c|}{ Cell Lines } \\
\hline & 93 & 117 & 118 & 119 & 120 & 121 \\
\hline MCT118 & $26 / 28$ & $26 /-$ & $26 /-$ & $26 / 28$ & $26 /-$ & $26 / 28$ \\
\hline CSF1PO & $9 / 10$ & $-/ 10$ & $-/ 10$ & $9 / 10$ & $-/ 10$ & $9 / 10$ \\
\hline FESFPS & $10 / 11$ & $10 /-$ & $10 /-$ & $10 / 11$ & $10 /-$ & $10 / 11$ \\
\hline THOI & 7 & 7 & 7 & 7 & 7 & 7 \\
\hline vWF & $16 / 18$ & $16 / 18$ & $16 / 18$ & $16 / 18$ & $16 / 18$ & $16 / 18 / 20$ \\
\hline YNZ22 & $1 / 2$ & -12 & $1 / 2$ & $1 / 2$ & $1 / 2$ & $1 / 2$ \\
\hline F13AOl & 7 & 7 & 7 & 7 & 7 & 7 \\
\hline TPOX & $8 / 12$ & $8 / 12$ & $8 / 12$ & $8 / 12$ & $8 / 12$ & $8 / 12$ \\
\hline HPRTB & 15 & 15 & 15 & 15 & 15 & 15 \\
\hline Fl3B & $6 / 10$ & $6 / 10$ & $6 / 10$ & $6 / 10$ & $6 / 10$ & $6 / 10$ \\
\hline LPL & $10 / 13$ & $10 / 13$ & $10 / 13$ & $10 / 13$ & $10 / 13$ & $10 / 13$ \\
\hline
\end{tabular}

line at seven FLP loci that all of the putative HeLa cell lines tested here are in fact HeLa derivatives. However, the three "atypical" Hela lines contain only one of the two HeLa alleles at FLP loci MCT118, CSFIPO, FESFPS, and YNZ22. This clearly indicates that during in vitro culture or after in vitro exposure to various treatments, these "atypical" HeLa lines have lost heterozygosity (i.e., they have become hemizygous).

The discrimination power of any given AmpFLP fingerprint is determined by the product of the frequencies of the component single locus genotype frequencies. The frequency of a genotype at any given polymorphic locus depends on the relative frequencies of each individual allele at that locus in the population to which that genotype belongs. In general, if $P_{m}$ and $P_{n}$ are the frequencies of alleles $A_{m}$ and $A_{n}$, and the allele frequencies are in Hardy-Weinberg equilibrium, then the expected proportions of genotypes at autosomal loci are $p_{m}{ }^{2}$ for true homozygotes $A_{m} A_{m}, P_{n}{ }^{2}$ for true homozygotes $A_{n} A_{n}$, and $2 p_{m} p_{n}$ for heterozygotes $A_{m} A_{n}$. A rough estimate of the frequency of the most common genotype obtained with AmpFLP testing of cell lines at different numbers of loci can be accomplished with genotype frequency data obtained in the normal population (Table 2). The average frequency of the most common alleles at each locus is roughly 0.4 , and the average frequency of heterozygosity at each locus in the normal population is roughly 0.7 . If one assumes that cell lines are derived from a random sample of the human population, then a heterozygous cell line genotype would be more likely to be observed than a homozygous cell line genotype at any given locus.

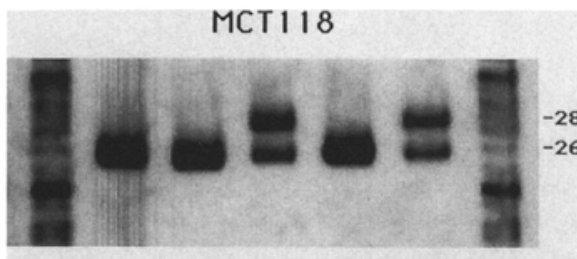

YNZ22

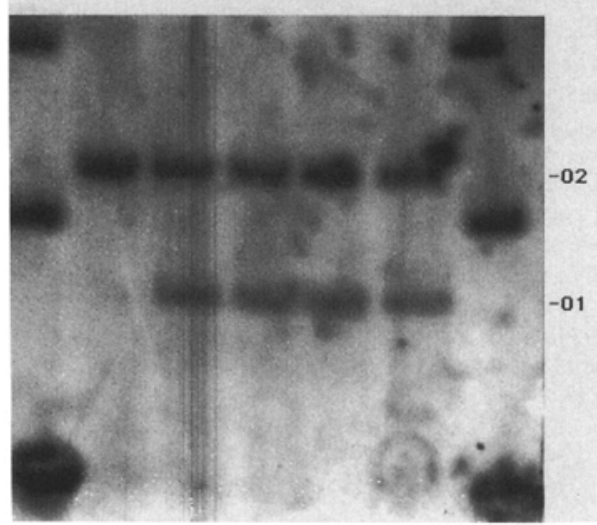

CSF1PO

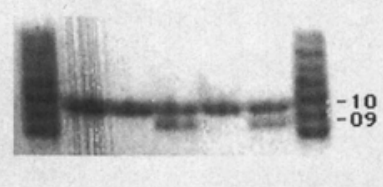

THO1

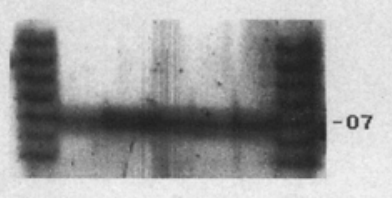

F13A01

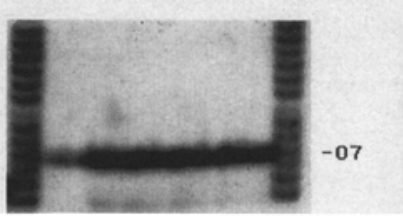

TPOX

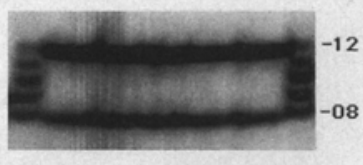

VWF

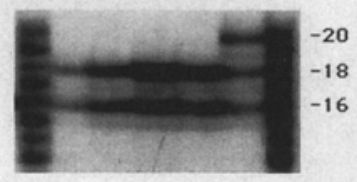

HPRTB

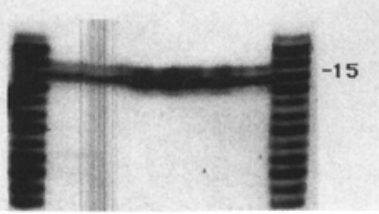

F13B

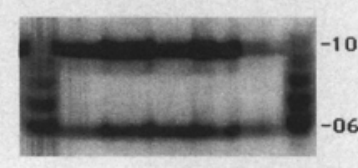

FESFPS

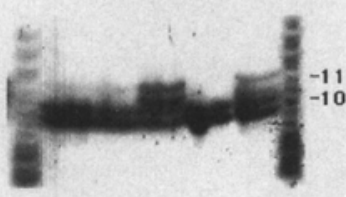

LPL

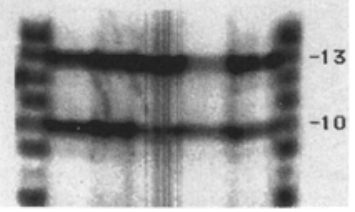

FIG. 3. DNA fingerprinting of five "HeLa" cell lines at 11 FLP loci. The first lane and the last lane are the allelic ladders of the corresponding locus, except for locus YNZ22, which is the 100-bp DNA ladder (the 100, 200, and 300 bp bands are shown). The sample lanes from left to right are cell lines 117, 118, 119, 120, and 121. The alleles of each cell line at each locus are listed in Table 3 . 
One would therefore predict that the most common AmpFLP cell line genotype for $n$ loci would be the product of the probabilities of the most common heterozygous genotype at each locus. Making the conservative assumption that the frequency of the second most common allele at any given locus is roughly equal to the frequency of the most common allele at that locus, this can be approximated as $2\left(P_{\mathrm{m}}\right.$

allele $)\left(P_{\text {second most common allele }}\right)^{n}=2(0.4)(0.4)^{n}=0.32^{n}$. As a preliminary estimate, the most common genotype might then occur with frequencies of the order of $0.32,0.10,0.03,0.01,0.003$, and 0.001 for 1 , $2,3,4,5$, or 6 FLP loci, respectively. It should be noted that the occurrence of cell line hemizygosity has not been taken into account in this calculation. Nevertheless, as a rough and conservative approximation, determination of the composite AmpFLP fingerprint of a cell line at six different FLP loci should achieve a minimum discrimination power of 0.999 , i.e., the chance of an unrelated cell line matching that fingerprint should be less than 0.001 .

One can further amplify the power of distinguishing cell lines by adding FLP loci to the AmpFLP fingerprint panel, by combining the AmpFLP allele frequency products with those of the isoenzyme phenotypic frequency products, or by both. In this regard, we emphasized that DNA fingerprinting by itself may not always distinguish cell line subclones because changes at chromosome loci other than those of the tested FLP loci may distinguish one subclone from another. However, such changes may be associated with detectable and consistent alterations in the number and appearance of chromosomes, the isoenzyme phenotype, or both. Therefore, the combined results of DNA fingerprinting, isoenzyme phenotyping, and chromosome analysis should permit the most informative analysis. During the past 20 years, we have developed a reference isoenzyme database on over 6000 different cell lines which, together with chromosome analysis, has proven extremely useful in cell line identification and authentication. On the basis of the demonstrated ability of AmpFLP to detect precisely and accurately the FLP alleles for cell lines at multiple polymorphic FLP loci, we are currently using this method to develop a cell line DNA fingerprint reference database as a powerful additional tool for future cell line identification and authentication.

\section{ACKNOWLEDGMENTS}

We thank Ward D. Peterson, Jr., D. Phil., for a critical reading of the manuscript, and Pippa Simpson, D. Phil., for statistical consultation. This study was supported by National Cancer Institute contract NO1-CP-33063.

\section{REFERENCES}

1. Brand, K. G.; Syverton, J. J. Results of species-specific hemagglutination tests on "transformed" nontransformed, and primary cultures. J. Nat. Cancer Inst. 28:147; 1962.

2. Gartler, S. M. Genetic markers as tracers in cell culture. Second Decennial Review Conference on Cell Tissue and Organ Culture. Nat. Cancer Inst. Monogr. 26:167-195; 1967.

3. Gartler, S. M. Apparent HeLa contamination of human heteroploid cell lines. Nature 217:750-751; 1968.

4. Gilbert, D. A.; Reid, Y.; Gail, M., et al. Application of DNA fingerprints for cell-line individualization. Am. J. Hum. Genet. 47:499-514; 1990.
5. Greene, A. E.; Coriell, L. L.; Charney, J. J. A rapid cytotoxic antibody test to determine species of cell cultures. J. Nat. Cancer Inst. 32:779$7861 ; 1964$.

6. Hukku, B.; Ottenbreit, M. J.; Rhim, J., et al. Marker chromosomes and isoenzyme shifts in a tumor cell line. Mammalian Chromosome Newslett. 24:149; 1983.

7. Hukku, B.; Halton, D. M.; Mally, M., et al. Cell characterization by use of multiple genetic markers. In: Acton, R. T.; Lynn, J. D., ed. Eukaryotic cell cultures. New York: Plenum Press; 1984:13-32.

8. Hukku, B.; Ellmore, N.; Aronson, S. A., et al. Cytogenetics of 52 tumor cell lines grown in-vitro. Cancer Gen. Cytogenet. 19:185; 1986.

9. Jeffreys, A. J.; Wilson, V.; Thein, S. L. Hypervariable minisatellite regions in human DNA. Nature 314:67-73; 1985.

10. Jeffreys, A. J.; Macleod, A.; Tamaki, K., et al. Minisatellite repeat coding as a digital approach to DNA typing. Nature 354:204-209; 1991.

11. Kasai, K.; Nakamura, Y.; White, R. Amplification of a variable number of tandem repeats (VNTR) locus (pMCT118) by the polymerase chain reaction (PCR) and its application to forensic science. J. Forensic Sci. 35:1196-1200; 1990.

12. Miller, O. J.; Miller, D. A.; Allerdice, P. W., et al. Quinacrine fluorescent karyotypes of human diploid and heteroploid cell lines. Cytogenetics 10:338-346; 1971.

13. Nakamura, Y.; Leppert, M.; O'Connell, P., et al. Variable number of tandem repeat (VNTR) markers for human gene mapping. Science 235:1616-1622; 1987.

14. Nelson-Rees, W. A.; Flandermeyer, R. R.; Hawthorne, P. K. Distinctive banded marker chromosomes of human tumor cell lines. Int. J. Cancer $16: 74-82 ; 1975$.

15. Nelson-Rees, W. A.; Flandermeyer, R. R. HeLa cultures defined. Science 191:96-98; 1976.

16. Nelson-Rees, W. A.; Hunter, L.; Darlington, G. J., et al. Characteristics of HeLa strains: permanent vs. variable features. Cytogenet. Cell Genet. 27:216-231; 1980.

17. O’Brien, S. J.; Kleiner, G.; Olson, R., et al. Enzyme polymorphism as genetic signatures in human cell cultures. Science 195:1345-1348; 1977.

18. Ottenbreit, M. J.; Halton, D. M.; Peterson, W. D., Jr. Rapid isoenzyme analysis of cell cultures by agarose electrophoresis II. Intraspecies identification of human cell lines. J. Tissue Culture Methods 8:125129; 1983.

19. Reid, Y. A.; Gilbert, D. A.; O'Brien, S. J. The use of DNA hypervariable probes for human cell line identification. ATCC Quart. Newslett. $10: 1-3 ; 1990$.

20. Reid, Y. A.; Lou, X. The use of PCR-amplified hypervariable regions for the identification and characterization of human cell lines. In Vitro 29A:120A; 1993.

21. Rothfels, F. H.; Axelrad, A. A.; Simonovitch, L., et al. The origin of altered cell lines from mouse, monkey, and man as indicated by chromomes and transplantation studies. Proc. Can. Cancer Res. Conf. 3:189-214; 1959.

22. Saiki, R. K.; Walsh, P. S.; Levenson, C. H., et al. Genetic analysis of amplified DNA with immobilized sequence specific oligonucleotide probes. Proc. Natl. Acad. Sci. USA 86:6230-6234; 1989.

23. Simpson, W. F.; Stulberg, C. S. Species identification of animal cell strains by immunofluorescence. Nature 199:616-617; 1963.

24. van Helden, P. D.; Wiid, I. J.; Albrecht, C. F., et al. Cross-contamination of human esophageal squamous carcinoma cell lines detected by DNA fingerprinting analysis. Cancer Res. 45:5660-5662; 1988.

25. Weber, J. L.; May, P. E. Abundant class of human DNA polymorphisms which can be typed using the polymerase chain reaction. Am. J. Hum. Genet. 44:388-396; 1989.

26. Wolff, R. K.; Nakamura, Y.; White, R. Molecular characterization of a spontaneously generated new allele at a VNTR locus: no exchange of flanking DNA sequence. Genomics 3:347-351; 1988.

27. Wright, W. C.; Daniels, W. P.; Fogh, J. Distinction of seventy-one cultured human tumor cell lines by polymorphic enzyme analysis. J. Nat. Cancer Inst. 66:239-247; 1981. 